\title{
Can grants affect student performance? Evidence from five Italian universities
}

Citation for published version (APA):

Graziosi, G., Sneyers, E., Agasisti, T., \& De Witte, K. (2021). Can grants affect student performance? Evidence from five Italian universities. Journal of Higher Education Policy and Management, 43(1), 24-48. https://doi.org/10.1080/1360080x.2020.1737343

Document status and date:

Published: 02/01/2021

DOI:

10.1080/1360080x.2020.1737343

Document Version:

Publisher's PDF, also known as Version of record

Document license:

Taverne

Please check the document version of this publication:

- A submitted manuscript is the version of the article upon submission and before peer-review. There can be important differences between the submitted version and the official published version of record.

People interested in the research are advised to contact the author for the final version of the publication, or visit the DOI to the publisher's website.

- The final author version and the galley proof are versions of the publication after peer review.

- The final published version features the final layout of the paper including the volume, issue and page numbers.

Link to publication

\footnotetext{
General rights rights.

- You may freely distribute the URL identifying the publication in the public portal. please follow below link for the End User Agreement:

www.umlib.nl/taverne-license

Take down policy

If you believe that this document breaches copyright please contact us at:

repository@maastrichtuniversity.nl

providing details and we will investigate your claim.
}

Copyright and moral rights for the publications made accessible in the public portal are retained by the authors and/or other copyright owners and it is a condition of accessing publications that users recognise and abide by the legal requirements associated with these

- Users may download and print one copy of any publication from the public portal for the purpose of private study or research.

- You may not further distribute the material or use it for any profit-making activity or commercial gain

If the publication is distributed under the terms of Article $25 \mathrm{fa}$ of the Dutch Copyright Act, indicated by the "Taverne" license above, 


\title{
Can grants affect student performance? Evidence from five Italian universities
}

\author{
Grazia Graziosi $\left(\mathbb{D}^{\mathrm{a}}{ }^{\mathrm{a}}\right.$, Eline Sneyers ${ }^{\mathrm{b}}$, Tommaso Agasisti $\left(\mathbb{D}^{\mathrm{c}}\right.$ and Kristof De Witte $\mathbb{D}^{\mathrm{d}, \mathrm{e}}$
}

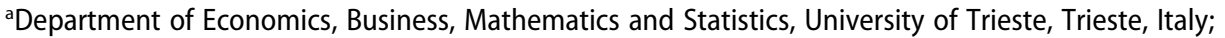

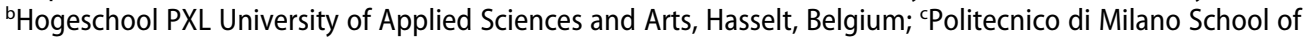
Management, Milano, Italy; 'Leuven Economics of Education Research, Faculty of Business and Economics, KU Leuven, Leuven, Belgium; ${ }^{\mathrm{e}}$ Top Institute for Evidence-Based Education Research, Maastricht University, Maastricht, The Netherlands

\begin{abstract}
This paper assesses the effect of need-based grants on the performance of university students in Italy. We performed a series of between-universities and within-universities propensity score matching analyses to evaluate the effect of grants on several student performance indicators, such as dropout rate, first year credits and efficiency of study. Our findings suggest that financial aid has a positive, substantial and statistically robust effect on university students' performance and on if and when they complete their undergraduate degree courses. The positive impact is heterogeneous across universities, while few differences were detected for subgroups of students. Reinforcing financial aid policies can simultaneously help disadvantaged students and improve overall academic performance in Italian universities.
\end{abstract}

\section{KEYWORDS}

Financial aid; Italian higher education system; propensity score matching

\section{Introduction}

Over the past ten years, attainment levels in tertiary education have grown significantly across much of Europe and the student population is becoming progressively more heterogeneous (OECD, 2017a). There are, however, persisting inequalities in European higher education systems concerning both access to and completion of tertiary studies. Students from a lower socio-economic background, as measured through their parents' employment status, have less chance to access higher education in most European countries (European Commission/EACEA/Eurydice, 2018). The parental level of education of the students strongly affects the likelihood of the students themselves obtaining a tertiary degree. Among the age group of 30-44 year-old with non-tertiary-educated parents, the share of those who have completed tertiary education is less than half the share of those with tertiary-educated parents (OECD, 2017b).

Governments are addressing the issue of access to tertiary education and equal opportunity by providing several forms of public support and financial aid to students and their families, including income-based and merit-based financial aid (i.e. grants and scholarships), loans, tax allowances for students or their parents and other state-granted benefits.

CONTACT Grazia Graziosi ggraziosi@units.it Department of Economics, Business, Mathematics and Statistics, University of Trieste, Trieste, Italy

4 Supplemental data for this article can be accessed here. 

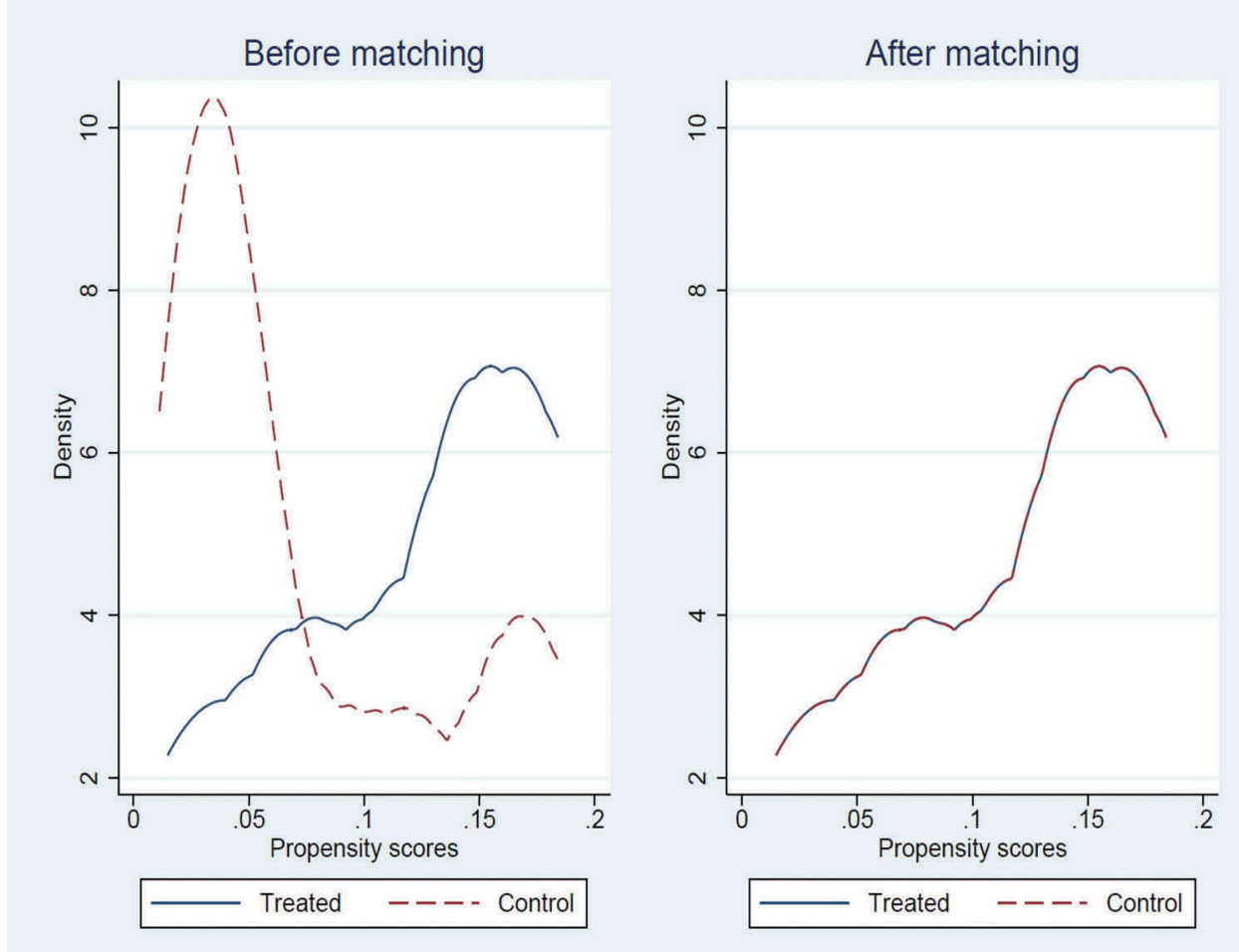

Figure 1. University $A$.

Panel A: Density plot of the propensity scores for the treatment and control group before matching for the number of formative credits in the first year and the first-year dropout.Panel B: Density plot of the propensity scores for the treatment and control group after matching for the number of formative credits in the first year and the first-year dropout.

This paper evaluates the effect of income-based state grants on students, employing a unique, micro data set collected by the researchers with support from the administrative offices of five universities located in the North of Italy. Italy makes an interesting case for studying the effects of need-based grants, because the Italian government offers state grants mostly to target groups, according financial aid based both on merit and on the students' family income. The objective of this state-provided financial aid is to lower the economic barriers for deserving students from a disadvantaged background and reduce socio-economic inequalities, as set out explicitly in the Italian Constitution. Despite these efforts, social inequality is noticeable when the percentages of students completing tertiary education are taken into account (Bratti, Checchi, \& de Blasio, 2008; Checchi, Fiorio, \& Leonardi, 2013).

We carried out a series of cross-sectional (between-universities) and within-universities analyses to evaluate the effect of grants on several student performance indicators. Furthermore, we were also interested in how the grants affected different subpopulations of students. We modelled the grant effects on student performance indicators, using the technique known as Propensity Score Matching (PSM) to reduce bias in the estimation of the effect of "treated' subjects linked to observational data. This paper is innovative for several 


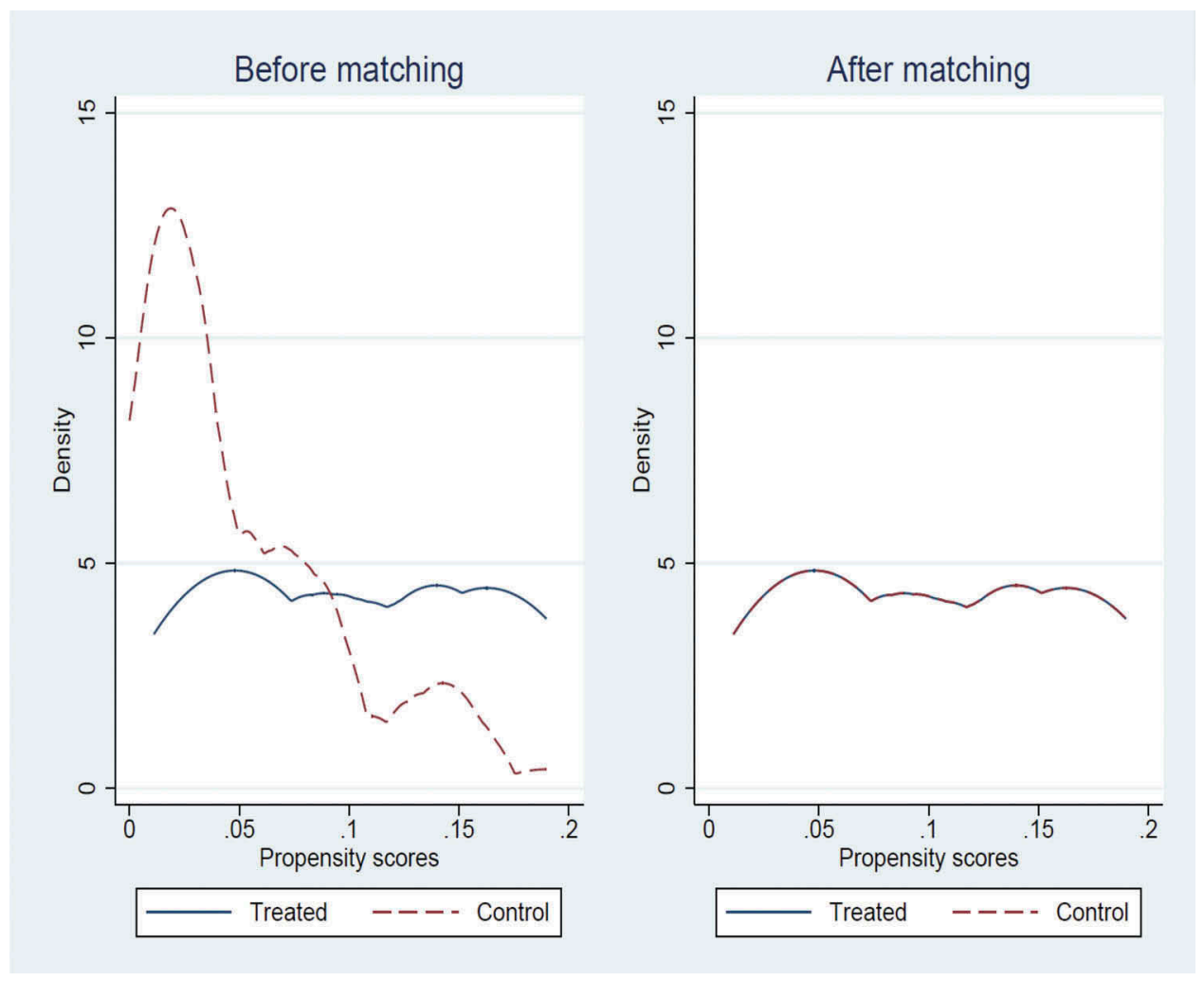

Figure 2. University $A$.

Panel A: Density plot of the propensity scores for the treatment and control group before matching for graduation in time and graduation within 4 years.Panel B: Density plot of the propensity scores for the treatment and control group after matching for the number of formative credits in the first year and the first-year dropout.

reasons. Firstly, it provides empirical evidence about how effective financial aid is on the probability that a student will graduate within the Italian higher education system. Previous work mostly focused on single universities or short-term effects, such as enrolment rates and dropout rates by the end of first year, while neglecting long-term effects such as graduation rates. Secondly, this paper contains an empirical analysis that specifically explored the heterogeneous effect of financial aid, comparing subpopulations of students with similar characteristics, grouped according to their origin, status and degree course in which they are enrolled. Finally, the paper examines the effectiveness of a grant with respect to the degree course. As undergraduate courses differ in terms of student selection process, programme requirements and the work demanded to pass exams, the impact of financial aid also highlights both the students' ability and their actual motivation.

The paper is organised as follows: Section 2 presents a literature review on the effects of providing financial aid to university students; Section 3 covers the characteristics of such financial aid in the Italian higher education system. Section 4 provides details on the method we used to analyse the data presented in Section 5. The results on both between and within universities are reported in Section 6 and the discussion and conclusions are presented in Section 7. Details of the robustness tests supporting our estimates are 


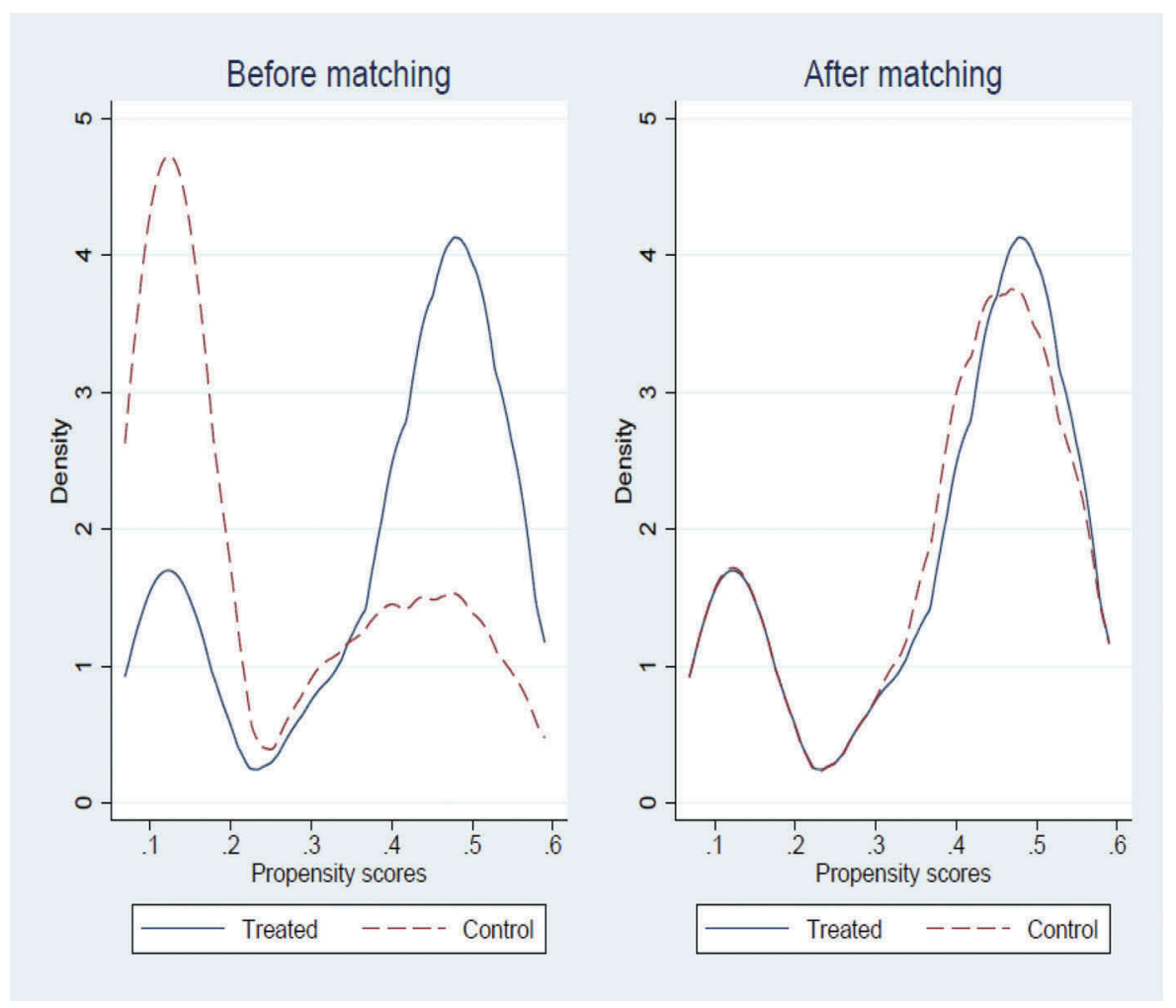

Figure 3. University $B$.

Panel A: Density plot of the propensity scores for the treatment and control group before matching for the number of formative credits in the first year and the first-year dropout.Panel B: Density plot of the propensity scores for the treatment and control group after matching for the number of formative credits in the first year and the first-year dropout.

provided in the Appendix available online, where we have also shown that the matching quality was verified through balance checking.

\section{Literature review}

The effect of university financial aid on student enrolment has been widely investigated in the literature, especially in the USA. A recent review by Page and Scott-Clayton (2016) suggests that enrolment increases when the net price faced by students is exogenously lowered, but little evidence is provided on the long-term effects of need-based grants, such as on performance and graduation. One of the few studies that consider several dimensions of student performances and graduation, by Page, Kehoe, Castleman, and Sahadewo (2017), investigated the effectiveness of the Dell Scholars Program, a scheme that provides a mix of financial support to selected students throughout the USA. Employing a Regression Discontinuity (RD) design in combination with a differencein-differences (DID) approach, the authors found that there was a higher probability that these selected students would graduate (from 6 percent to 13 percent). Castleman and Long (2016) examined the impact of the Florida Student Access Grant (FSAG) on long- 


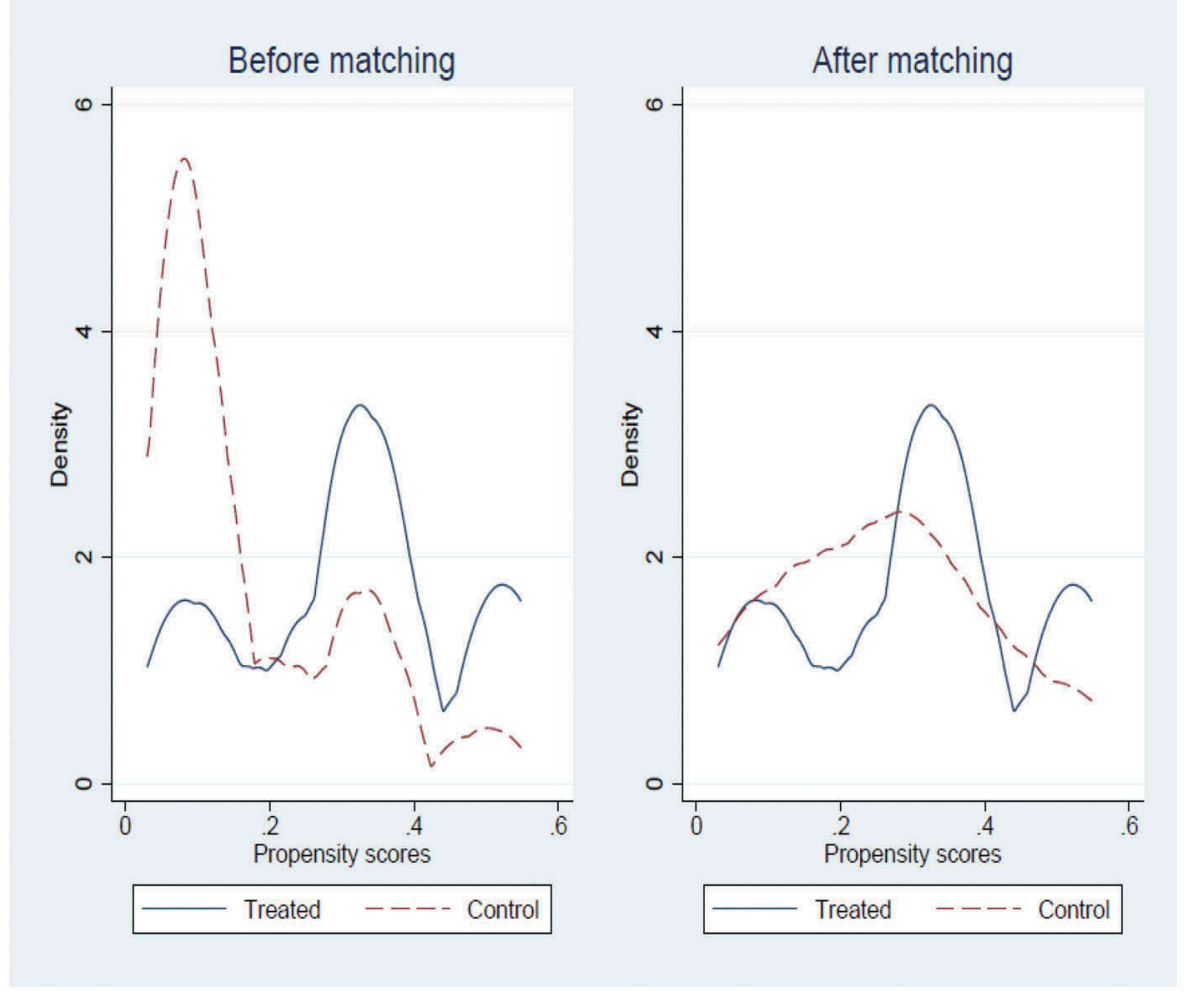

Figure 4. University $B$.

Panel A: Density plot of the propensity scores for the treatment and control group before matching for graduation in time and graduation within 4 years.Panel B: Density plot of the propensity scores for the treatment and control group after matching for the number of formative credits in the first year and the first-year dropout.

term outcomes such as college persistence rate and degree completion rate. Using the $\mathrm{RD}$ strategy, the authors showed that financial aid positively affects student persistence and the cumulative number of credits that these students earned. Moreover, being awarded a grant also increases the likelihood of the student gaining a bachelor degree by a 4.6-point percentage. Lastly, Denning (2018), using data relating to students enrolled in public universities in Texas, estimated that additional financial aid accelerates graduation for lower-income students, but roughly 50 percent of the increased time to degree for the last 30 years is probably due to increases in the cost of attending university.

As far as the European context is concerned, there is still limited evidence on how financial aid influences higher education outcomes. Glocker (2011), applying a discrete-time duration model on German universities from 1984 to 2007, found that students who were given financial aid were less likely to drop out, but did not graduate any earlier. Arendt (2013) looked at several outcomes for academic performances in a study assessing the Danish reform to the student grant and loan system, where the amount of aid was increased. The results suggesting a positive impact on lowering the dropout rates may partially be explained by students with a job working for fewer hours while studying, as was the purpose of the Danish reform, but no overall effect was found on course completion rates. Lastly, Belot, Canton, and Webbink (2007) studied the impact of a reform to the Dutch higher education system which 


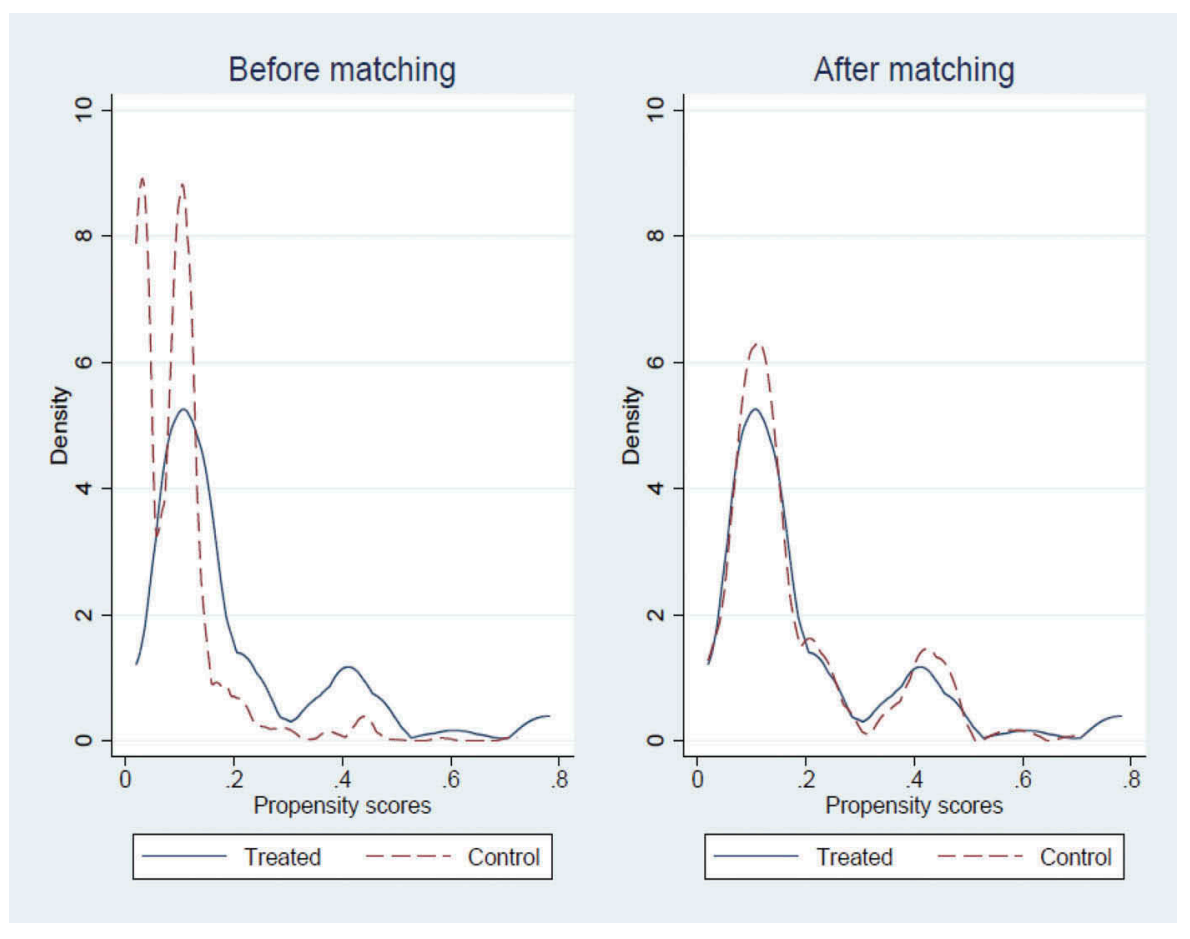

Figure 5. University $C$.

Panel A: Density plot of the propensity scores for the treatment and control group before matching for the number of formative credits in the first year and the first-year dropout.Panel B: Density plot of the propensity scores for the treatment and control group after matching for the number of formative credits in the first year and the first-year dropout.

reduced the length of (mostly merit-based) scholarships by one year. The authors considered several dimensions of academic performance - passing first-year exams, drop-out rates and graduation mark - showing, through a difference-in-differences approach, that the reform positively affected the students' results.

Among the Italian literature on the effect of higher education grants and scholarships, Mealli and Rampichini (2006) analysed the effect of financial aid on two aspects in the university education process: persistence (enrolment to the second year) and productivity (number of exams passed in the second year). The analysis focused on 11 universities evenly distributed throughout Italy and considered students enrolled in three academic years, 1998, 1999 and 2001. The effectiveness of being awarded a grant on the probability of the student enrolling to their second year was demonstrated only for 'far from home' students in 9 out of 11 observed universities, while a grant was almost never effective for commuters and resident students. Subsequently, Mealli and Rampichini (2012) studied the impact of a student having a grant on the probability of them dropping out, examining students enrolled in 1999 at four Italian universities. The authors showed that, the effect of a grant on retention decreases with their family's income, in line with the study by Garibaldi, Giavazzi, Ichino, and Rettore (2012). From their analysis, it appears that, if the grants were increased by $€ 1,000$, the probability that students would obtain their 


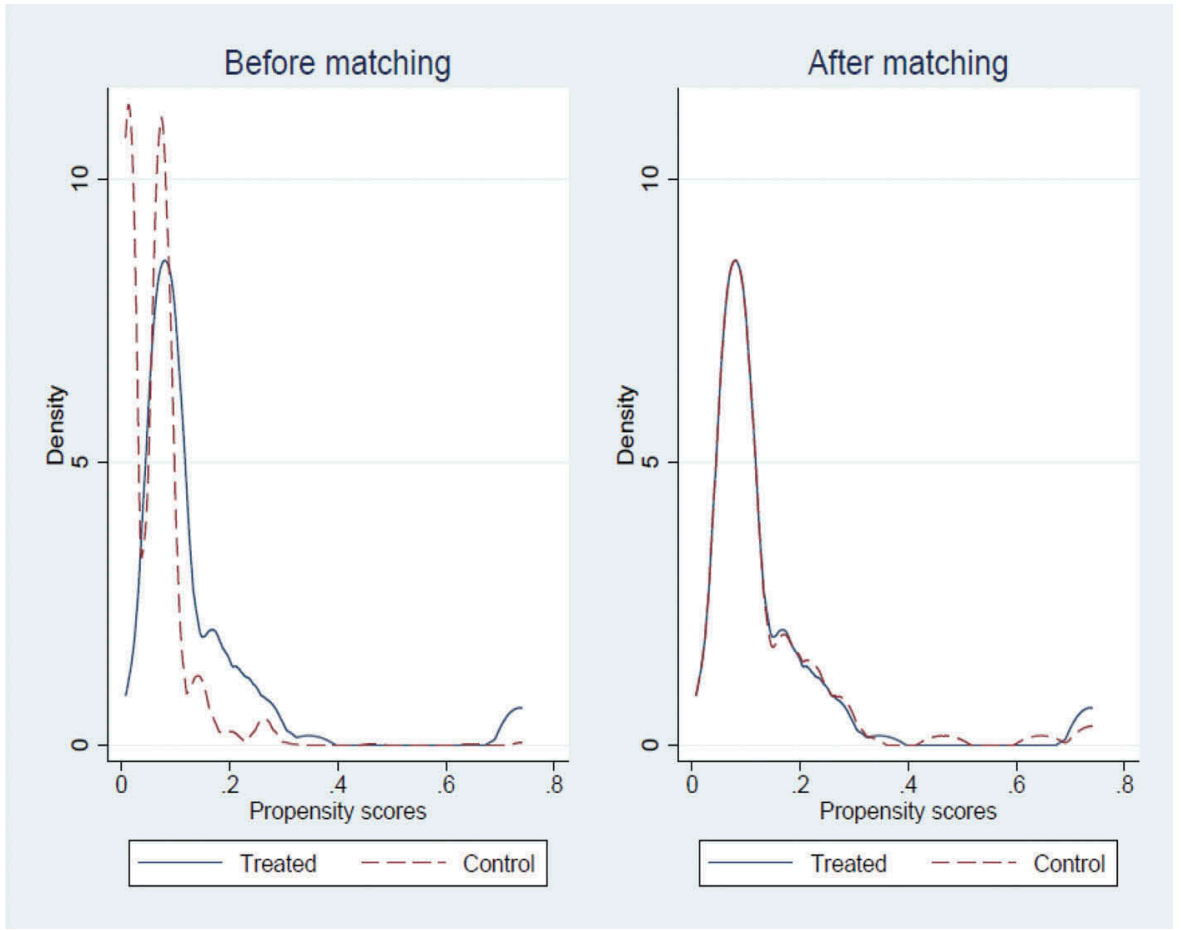

Figure 6. University $C$.

Panel A: Density plot of the propensity scores for the treatment and control group before matching for graduation in time and graduation within 4 years.Panel B: Density plot of the propensity scores for the treatment and control group after matching for the number of formative credits in the first year and the first-year dropout.

degree outside the standard time for their course would decrease by 5.2 percent. Graziosi (2014) investigated the impact of different forms of financial incentives - income-based grants and/or merit-based scholarships and/or loans - on both the probability of the student enrolling to their second year and of graduating within the regular time-frame at the University of Trieste. Applying matching techniques, the author demonstrated that income-based grants reduce the dropout rate, while merit-based grants helped students to graduate within their proper year. Lastly, Agasisti and Murtinu (2016) assessed the impact of being awarded a grant on a cohort of students enrolled at Politecnico di Milano in 2007/ 08. Their empirical analysis focused on a wide range of academic results, including dropout rate, university credits and time to graduation, as well as on various heterogeneous effects relating to the students' features and course. The authors found that obtaining a grant positively affected academic performance, especially for immigrants, students whose family live in another region and those taking engineering courses.

\section{Financial aid for students in the Italian higher education system}

The Italian student financial support system consists mainly of state-funded grants for specific groups of students, while other forms of help in the form of loans and state- 

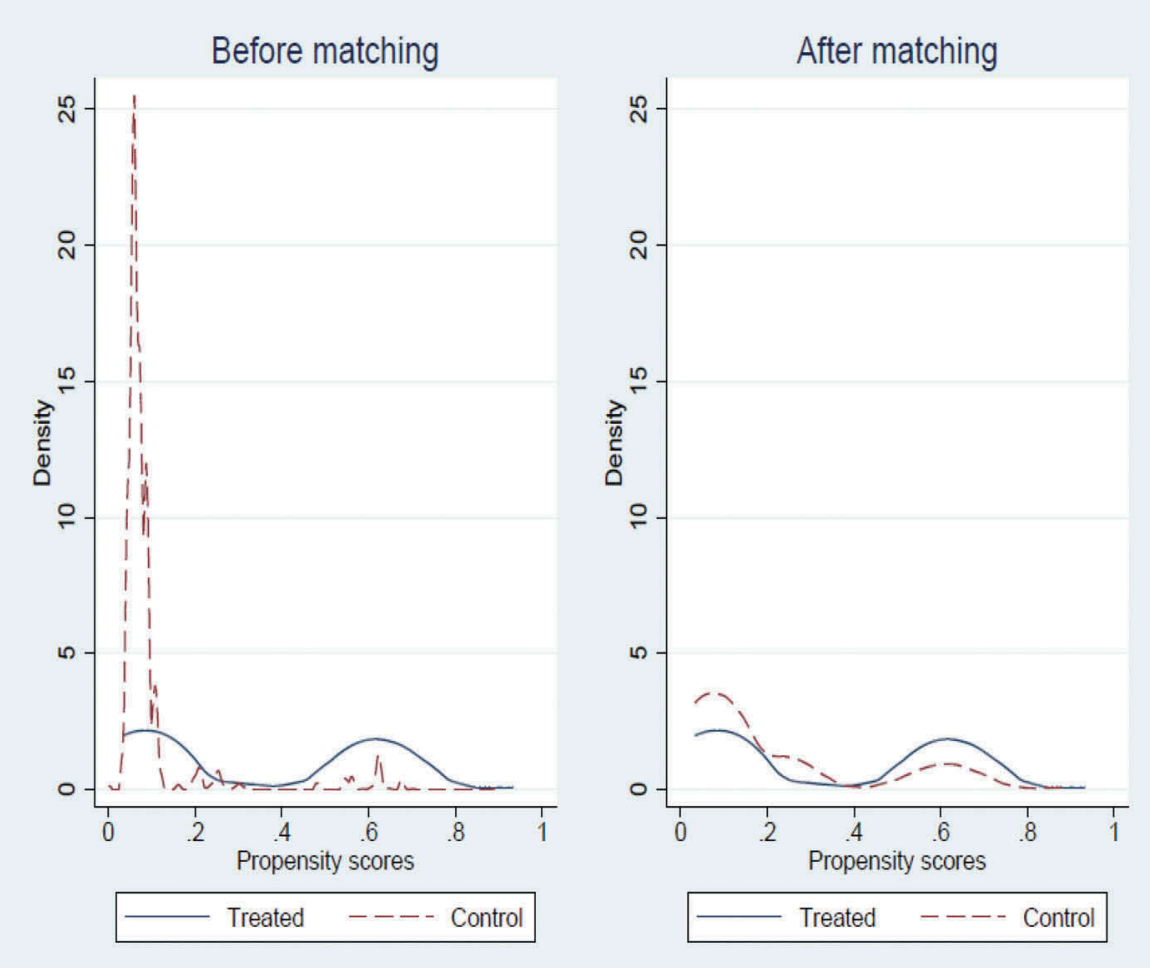

Figure 7. University $D$.

Panel A: Density plot of the propensity scores for the treatment and control group before matching for the number of formative credits in the first year and the first-year dropout.Panel B: Density plot of the propensity scores for the treatment and control group after matching for the number of formative credits in the first year and the first-year dropout.

granted benefits are negligible. On top of this, the main 'rules of the game' - such as eligibility criteria, the grant value, etc. - are defined centrally by the Ministry for Education and are not the direct responsibility of individual universities. Another key feature of the system is that it helps only a small percentage of students, around 19 per cent (OECD, 2017b) and depends heavily on public funding. In the years considered in the analysis (2007/08), on average just 13 per cent of students received a need-based grant, and the percentage was relatively lower in some regions (i.e. Campania and Lombardy: 8.9 per cent) and substantially higher in others (i.e. Piedmont: 17.9 per cent and Calabria: 19.3 per cent; source of data: Regional Observatory of the University System in Piedmont, northern Italy).

\section{Need-based grants}

In the financial aid system for 2007/2008 (the year under analysis in this study), students were ranked on the basis of their economic needs, measured through an indicator that considers family income and assets.

Grant applicants enrolled to the first year of university must provide proof of their family income, in the form of a set of official indicators, and, to be eligible for income- 


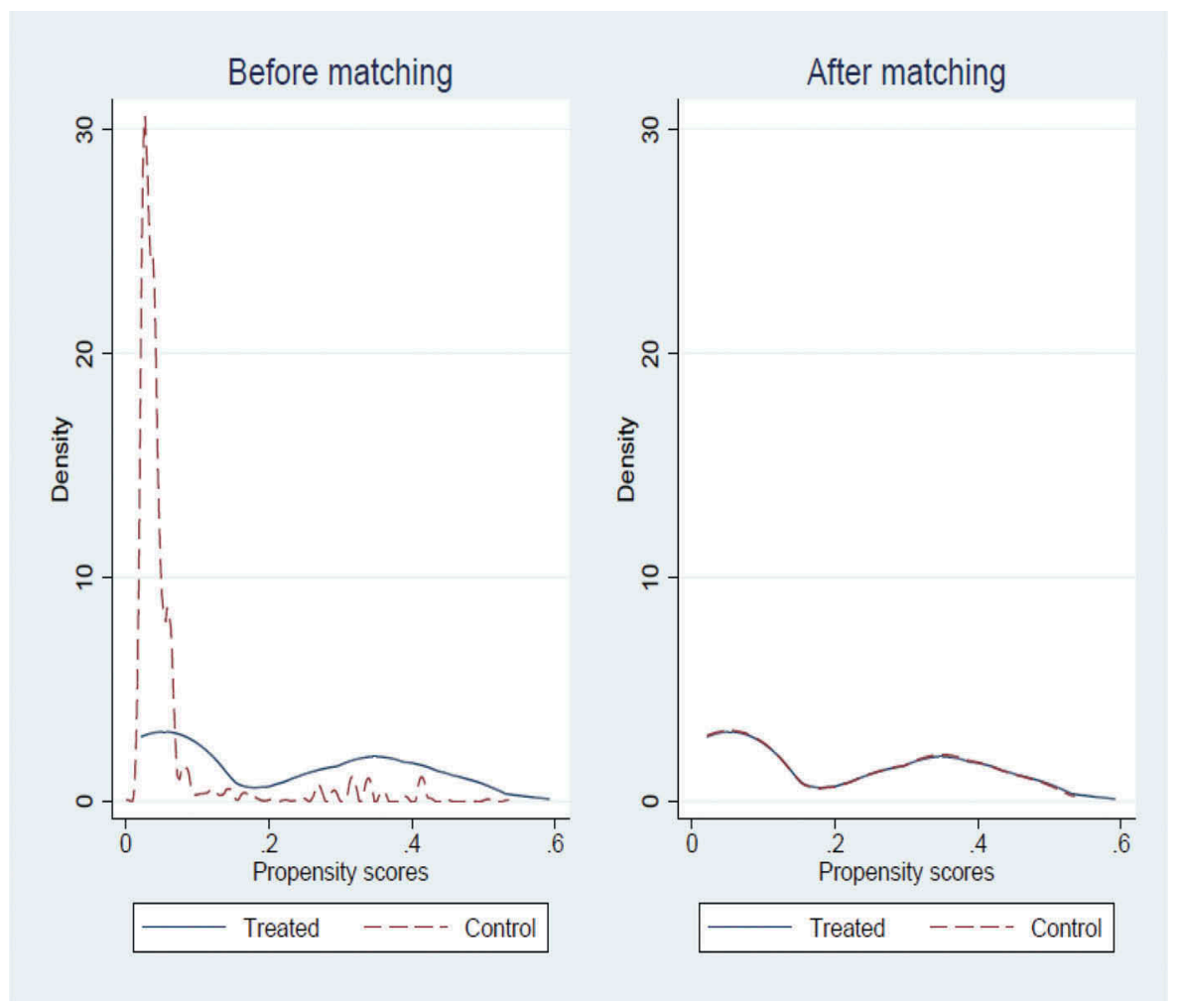

Figure 8. University $D$.

Panel A: Density plot of the propensity scores for the treatment and control group before matching for graduation in time and graduation within 4 years.Panel B: Density plot of the propensity scores for the treatment and control group after matching for the number of formative credits in the first year and the first-year dropout.

based grants, this must not exceed $€ 21,000$. Grant beneficiaries are exempt from university fees and receive the first part of their grant to cover living and studying costs. To retain their grant, students must acquire a certain number of university credits by mid-August. The number of credits depends on their degree course and typically between 20 and 40 credits (a full academic year is equivalent to 60 credits), are required for the student to go into their second year, and 80 credits to enter their third year. If students have not met the minimum number of credits required by the end of their first year, they do not receive the second and final part of their total grant. On top of this, if they do not meet the first-year requirements by the beginning of their second year, students must return the first half of their grant.

The value of their grant depends, as mentioned above, on the income indicators for the student and their family. It also varies according to where the students live. If the students' home is in the same city as their university, they are classified as 'near-home' students, if their home is near enough the city where they are at university for them to travel there every day, then they are 'commuting' students, and if their home is too far for them to do that, then they are classed as 'far-from-home' students. The combination of economic indicators and the student's status as defined above sets the value of the grant, from $€ 1,500$ to $€ 5,700$ per year, where the maximum sum is awarded to the most disadvantaged 'far- 


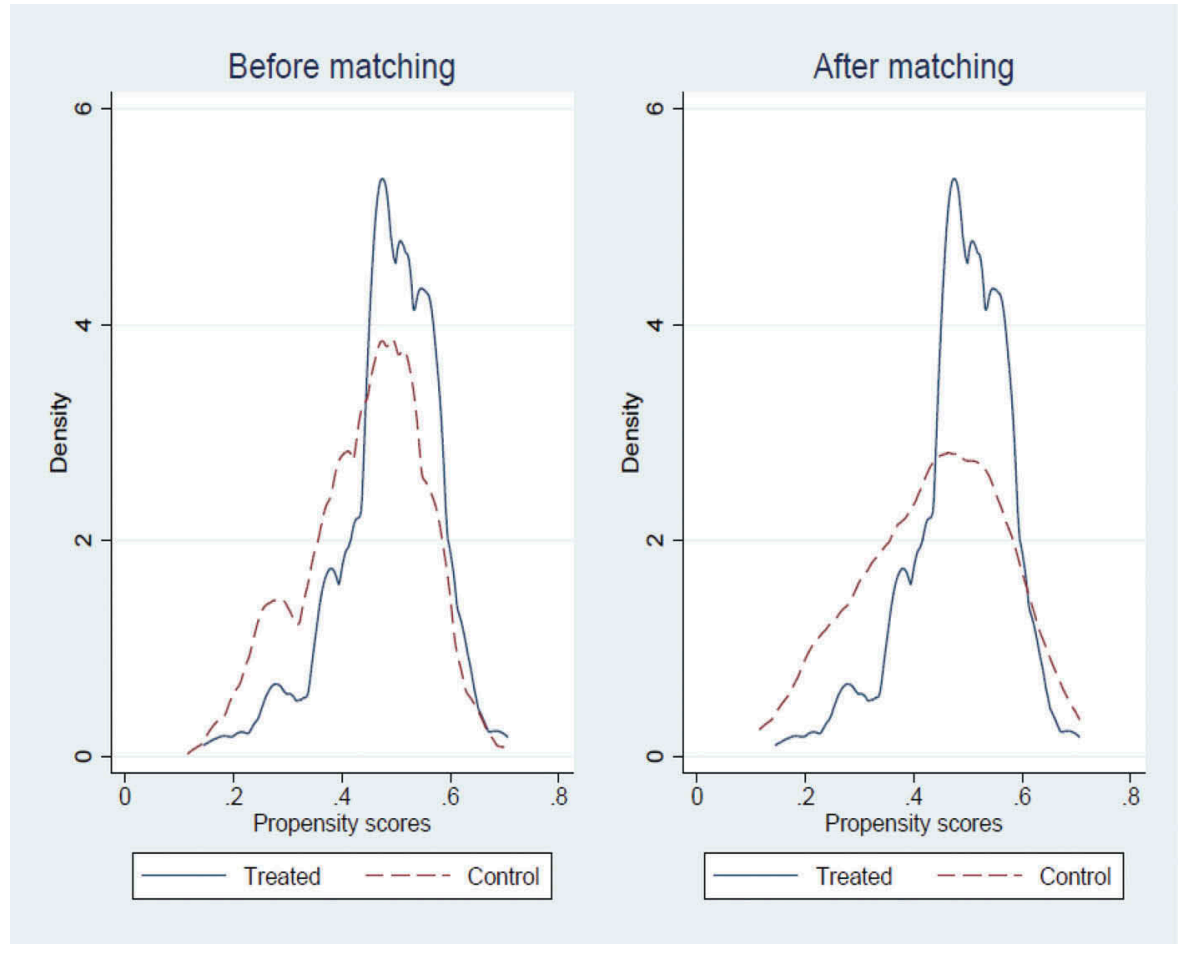

Figure 9. University $E$.

Panel A: Density plot of the propensity scores for the treatment and control group before matching for the number of formative credits in the first year and the first-year dropout.Panel B: Density plot of the propensity scores for the treatment and control group after matching for the number of formative credits in the first year and the first-year dropout.

from-home' students. Students awarded a grant do not pay tuition fees and as well as paying less or nothing for their living costs, such as meals and accommodation.

\section{Underlying mechanisms for need-based grants to be effective}

Having outlined the main features of the student support system, it is worth examining why it is reasonable to expect a grant to have an impact on student performance, and where we would expect to see the potential heterogeneity of this effect a priori. Firstly, a grant reduces a student's immediate need for cash. Many students, especially the most disadvantaged, are forced to work during their studies to cover their living costs. A grant can allow them to work for fewer hours and free up for studying (Avdic \& Gartell, 2015). Secondly, students who receive a grant could also benefit from a 'motivation effect' and often perform better than they would have done otherwise. This effect, of course, comes into play even more strongly for students receiving a scholarship earned through merit, driving them to make the most of this HE opportunity. Lastly, external pressure (from parents, friends, etc.) can also play a role as students are unwilling to let family and friends down. For all these reasons, our hypothesis is that receiving a grant can have 

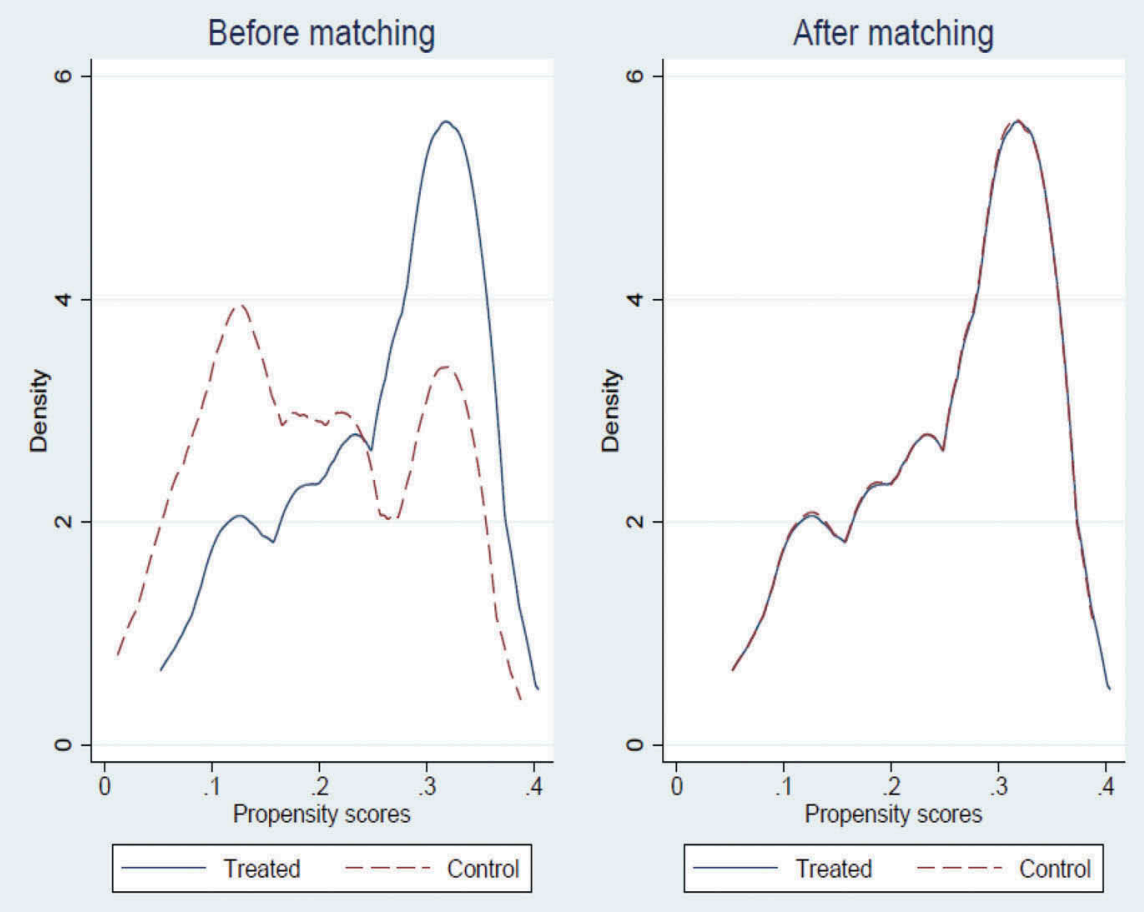

Figure 10. University $E$.

Panel A: Density plot of the propensity scores for the treatment and control group before matching for graduation in time and graduation within 4 years. Panel B: Density plot of the propensity scores for the treatment and control group after matching for the number of formative credits in the first year and the first-year dropout.

a direct and sizeable positive effect on the performance of selected students, when compared with other similar students who do not receive a grant.

There are also mechanisms leading us to expect that a need-based grant produces a heterogeneous set of effects. Firstly, since immigrants are less likely to enrol at university and have a higher probability of dropping out than Italian students, we expect immigrant students who are the recipients of a grant to be more motivated to continue their degree course (Cingano \& Cipollone, 2007). In addition, some studies (e.g. Catalano \& Figà Talamanca, 2002) have shown that the greatest cost in higher education is for accommodation. Therefore, relatively poor students who go to university in another region/city will need more financial help than students nearer to home. Furthermore, degree courses in different subjects vary in terms of the students' ability and commitment. Therefore, grants can have a heterogeneous impact on students enrolled in different fields of study.

\section{Methodology}

In order to investigate the effect that receiving a grant has on a student's performance, we have applied a counterfactual analysis. According to the potential outcome model, each student has two outcomes (Rubin, 1974): $Y^{T}$ represents the student's performance when they are the recipient of a grant (i.e. the Treated), $Y^{U T}$ represents the students' 
performance when they are not the recipient of a grant (i.e. Untreated). Since the two outcomes are mutually exclusive for any student, the outcome that is not observed is referred to as the counterfactual outcome (Holland, 1986) and it shows how treated students would behave if they had not been 'treated'.

The average effect of gaining a grant on the students' performance is the Average Treatment effect on the Treated (ATT), i.e. the average difference between $Y^{T}$ and $Y^{U T}$, conditionally to the treatment:

$$
A T T=E\left(Y^{T}-Y^{U T} \mid T=1\right)=E\left(Y^{T} \mid T=1\right)-E\left(Y^{U T} \mid T=1\right)
$$

where $T=\{0,1\}$ is the indicator of exposure to treatment.

The counterfactual outcome, $E\left(Y^{U T} \mid T=1\right)$, is unobserved and must be estimated with reference to the untreated student, balanced with respect to all explanatory variables.

Since, in observational studies, the assignment of units to the treatment is not random, the estimation of the treatment effect may lead to mistakes caused by selection bias. Propensity Score Matching (PSM) was applied to avoid this problem (Rosenbaum \& Rubin, 1983). Firstly, we defined the treated students (those who have a grant) and the untreated students (those who do not have a grant, and this is the control group). Then we employed PSM, i.e. the estimated probability $\hat{\pi}$ of being treated, to match each treated student with a student who is similar for all $\mathrm{X}$ pre-treatment variables.

This approach helped us to balance the control and treatment groups with respect to all pre-treatment variables that could affect the outcomes, and the ATT could be written as:

$$
\left.\widehat{A T T}^{P S}=E_{\pi(X) \mid T=1}\left\{E\left[Y^{T} \mid T=1, \hat{\pi}(X)\right]-E\left|Y^{U T}\right| T=0, \hat{\pi}(X)\right]\right\}
$$

where the average difference between the outcome of both treated and untreated students is weighted according to the distribution of the Propensity Score (PS).

The treatment is defined as:

- A student receiving a grant in their first academic year, if the outcomes are the number of credits obtained in their first year or dropping out at or by the end of the first year;

- A student receiving a grant in their first, second and third year, if the outcome is graduating (either within the regular time-frame of their course or after four years).

Although we have conditioned the matching procedure on the propensity score, it must be checked if the distribution of covariates is to be balanced in both the treatment and control group (Caliendo \& Kopeinig, 2008). The online Appendix contains the summary of the Absolute Standardised Bias (ASB) distribution before and after matching (Table 7), as well as the distribution of the PS before and after matching (Figures 1-10). These demonstrate the validity and statistical reliability of the procedure used here in the evaluation.

\section{Data}

We collected a unique dataset of first-year students enrolled at five large traditional universities in northern Italy. 
These five universities were chosen on the basis of three factors.

Firstly, we would be working with more than one university. Previous studies have focused on single cases (for example, Garibaldi et al. (2012), Graziosi (2014); Agasisti \& Murtinu, 2016), but our objective was to provide evidence from different universities (along the lines of Mealli \& Rampichini, 2012).

Secondly, we would maintain some degree of comparability among university under analysis. The gap between northern and southern Italy also holds true in the context of $\mathrm{HE}$, with universities located in the north, south and centre dealing with very different environments, and so making straightforward comparisons quite difficult. Student performance can be highly influenced by the socio-economic setting in which the universities are located. For this reason, we focused on universities in the north of Italy to avoid the influence of unobserved heterogeneity at the institutional level caused by environmental factors. Three of the universities are situated in northwest Italy. The smallest, University A, is specialised in communication strategies and foreign languages, i.e. humanities; University B offers undergraduate courses in architecture, design and engineering, i.e. sciences; and University $\mathrm{C}$ offers undergraduate courses in science, social sciences and medicine. The two other universities are in northeast Italy and teach a wide range of undergraduate courses. University D covers all academic subjects as does University E, but without medicine. Together, the five universities can provide evidence on four different fields of study: humanities (universities A, D and E), sciences (universities $\mathrm{B}, \mathrm{C}, \mathrm{D}$ and $\mathrm{E}$ ), social sciences (universities $\mathrm{C}, \mathrm{D}$ and $\mathrm{E}$ ) and medicine (universities $C$ and $D$ ).

Thirdly, several Italian universities were contacted by researchers asking for access to student-level data that could be used for comparison purposes in the analysis, and five universities responded positively and agreed to provide the specific variables and indicators requested, in part because they held this kind of information about the specific cohorts of students under analysis. These five became our selected universities. For all universities, except University E, we took the first-year students for the academic year 2007/2008. For University E, we took the first-year students for the academic year 2008/ 2009. We then followed the progress of a total of 7,415 students for four years (i.e. until the academic year 2010/11, or 2011/12 for University E).

In order to consider the most relevant student characteristics that simultaneously influenced both the treatment and the outcome (Sianesi, 2004), we included the following observable control variables: gender, type of secondary education school, regular student (i.e. students who enrol at university the year after completing their secondary education), a proxy for distance to the university and the students' socioeconomic status (SES). With respect to SES, we had no direct information on the students' family income, which meant that we were unable to apply an RD analysis, a common method where a threshold that defines treated and untreated units (our students) around a cut-off point. However, we were able to collect indirect information on the students' SES from their fees, as these are calculated on the basis of their family income and are submitted voluntarily by students applying for reduced tuition fees. It worth noting that not all students declare their economic situation and it is reasonable to assume that they do not need reduced fees or are less motivated in achieving the degree. Finally, we must also mention that we do not have information about the fee level paid by students (fees are means-tested and set according to the fee band for their 
family income) at universities $\mathrm{C}$ and $\mathrm{D}$. Therefore, we carried out a robustness check whereby we were able to exclude the information regarding the income level of these students from the estimation of the PS and results did not change significantly (see the online Appendix, Table 6).

We defined four output variables for the academic performance of students:

- the number of credits obtained by the students at or by the end of their first year;

- their dropout status at the end of their first year;

- graduation by the end of the regular three-year undergraduate course;

- graduation within four years.

Table 1 gives descriptive statistics on the treated and untreated students at each university. In this context, students who receive a grant are considered treated, and the untreated students (or control group) are students who qualify for a grant but have not received one, i.e. eligible students (except for universities $\mathrm{C}$ and $\mathrm{D}$ where we have no information on the students' income). The reasons why eligible students did not receive a grant is that they either did not submit all the necessary documentation on time, or did not apply for a grant despite meeting the criteria. We have, therefore, only included students in the control group who are both eligible and for whom there is no missing data. Our sample consists of 6,058 untreated students in the control group and 1,357 treated students with grants. We were able to observe some interesting differences between the control and treatment group. Firstly, the proportion of students who went through their course year by year without deferments, i.e. regular students, is slightly lower for the control group across the whole sample, but with interesting differences for single universities. Secondly, the proportion of near-home students is significantly higher in the control group, except for University E. Further, fewer students who received a grant, on average, attended an academic secondary school ('liceo') or a technical high school. For the unmatched sample, it is clear that the characteristics of students differ significantly for some of the variables.

\section{Results}

\section{The effect of the grants}

The estimated impact of receiving a grant on student performance is reported in Table 2 and points towards it having a positive impact for all performance indicators at all universities, except for the universities D and E. For these two universities, the impact of the grant is not significantly different from zero, with respect to the credits acquired by students and the first-year dropout rate.

A grant leads to students getting more credits, with an increase from 9.2 to 23.1 for universities $\mathrm{A}$ and $\mathrm{C}$. As students acquire more credits, they are less likely to drop out in their first year. For universities A, B and C, receiving a grant meant that students were less likely to drop out in their first year, with this outcome ranging from 0.034 to 0.228 (the change is expressed in absolute terms on the scale $0-1$ ), with respect to the mean.

Considering graduating on time and graduating within four years, we found that grants have a positive and significant effect at all universities, except for University A. We 


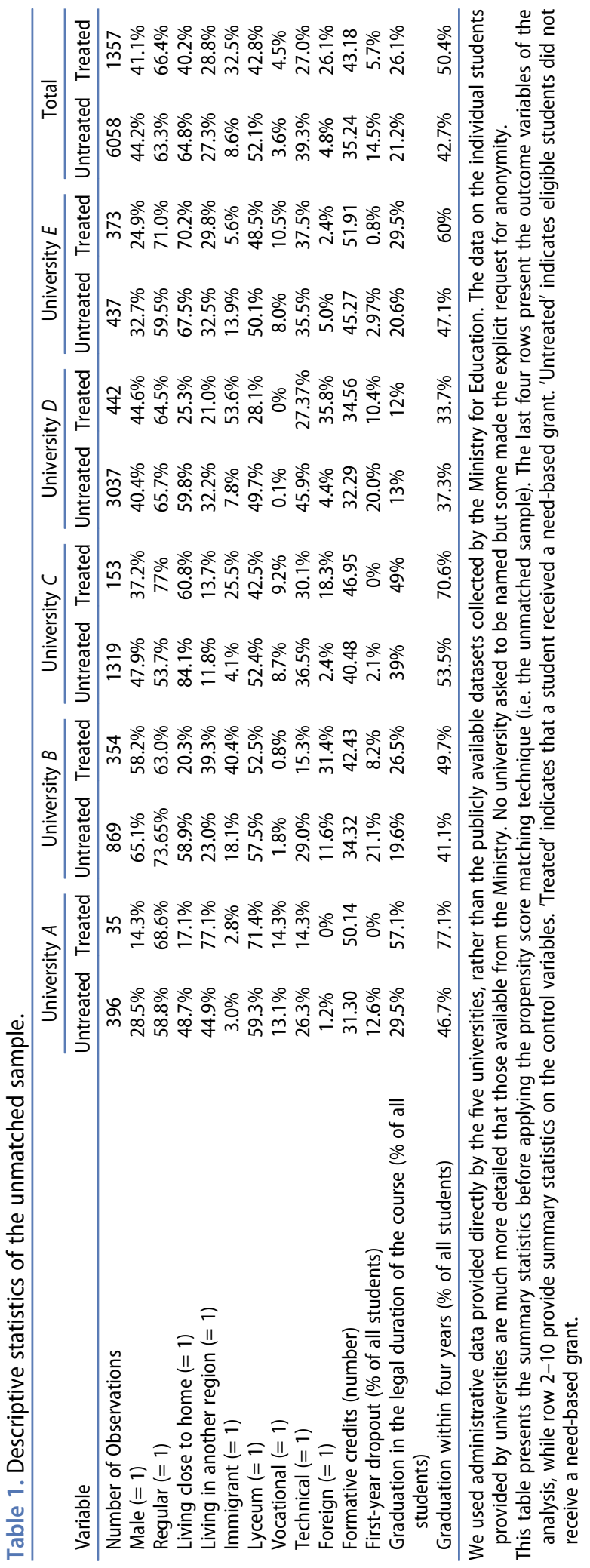




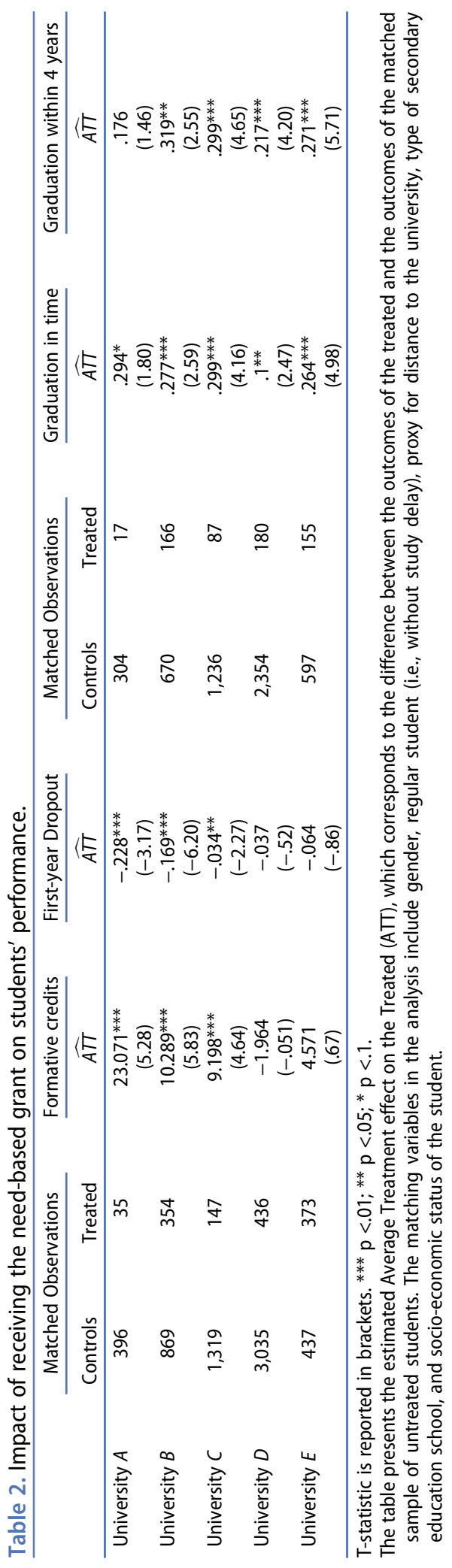


observed an increase in the probability of graduating on time within a $0.1-0.299$ range, while the probability of graduating within four years varied from 0.217 to 0.319 .

We can conclude that the impact of a grant is positive and relatively large for all performance indicators, especially in relation to student completing their undergraduate degree and graduating. The effect of the grant is to encourage students to complete their studies. At the same time, the observed differences in the effects across the five selected universities suggest there could be some institution-level factors that might have an impact on selected outcomes (i.e. the students' performance). On methodological grounds, this corroborates and justifies our choice of running empirical analyses separately university by university. From a policy viewpoint, it opens the door to future research into investigating university-level factors.

\section{The heterogeneous impact of the grants}

This section investigates whether the effect of receiving a grant is conducive to different results for (i) Italian vs. immigrant students, (ii) near-home students vs. students from different regions, and (iii) students taking different degree courses.

\section{Italian students vs immigrants}

The results presented in Table 3 do not provide a clear-cut pattern between the two subpopulations. The most prominent differences are observed at university level (noting that University A is excluded because of the excessively low number of observations for immigrant students).

In universities $B$ and $C$, grants have a positive significant impact on the number of credits acquired by immigrant students, where they achieve 17.1 and 12.6 credits, respectively. Given that the ATT is almost double for immigrants than for Italian students, it is likely that, as a mechanism, a lack of funds dominates the other mechanisms (see Section 3.2).

With respect to the first-year dropout rate, we did not find that receiving a grant reduces the probability of dropping out for either immigrant or Italian students, except for University B, where the dropout probability decreases significantly for Italian students only.

Grants have a positive influence on the subpopulation of Italian students with respect to the probability that they will graduate on time which is within a $0.13-0.30$ range, while the ATT is significant for both immigrant and Italian students with respect to the probability of graduating within four years. Summarising, a general positive effect for immigrant students is detectable in terms of the impact a grant has on them graduating within four years, and this point can catch the attention of policy makers as a means for promoting inclusion through financial aid.

\section{Near-home students versus students from other regions}

Within the group of Italian students, the impact of receiving a grant can be different between near-home students and students from other regions, as the latter group may be burdened with higher living costs and thus may benefit more from a grant. From Table 4, we were able to observe that students from other regions have a higher probability of acquiring credits at universities $\mathrm{A}$ and $\mathrm{C}$, while, for universities $\mathrm{D}$ and $\mathrm{E}$, there are no significant results in either group. Awarding grants to students from other regions results 


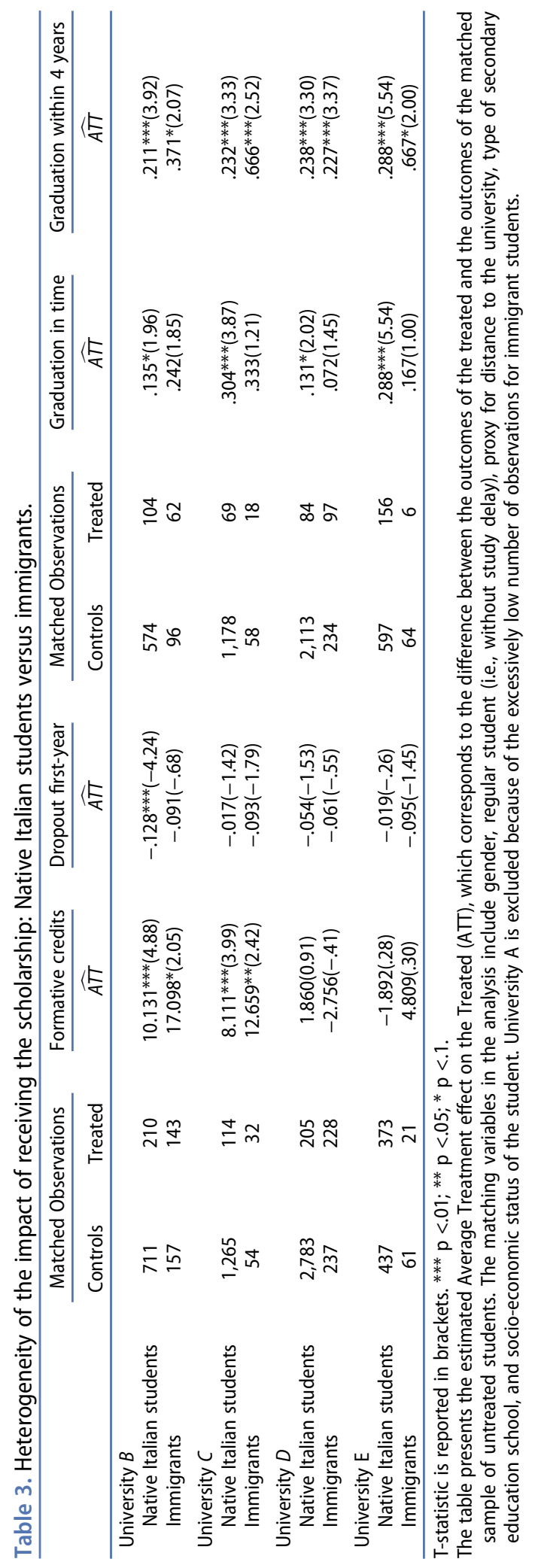




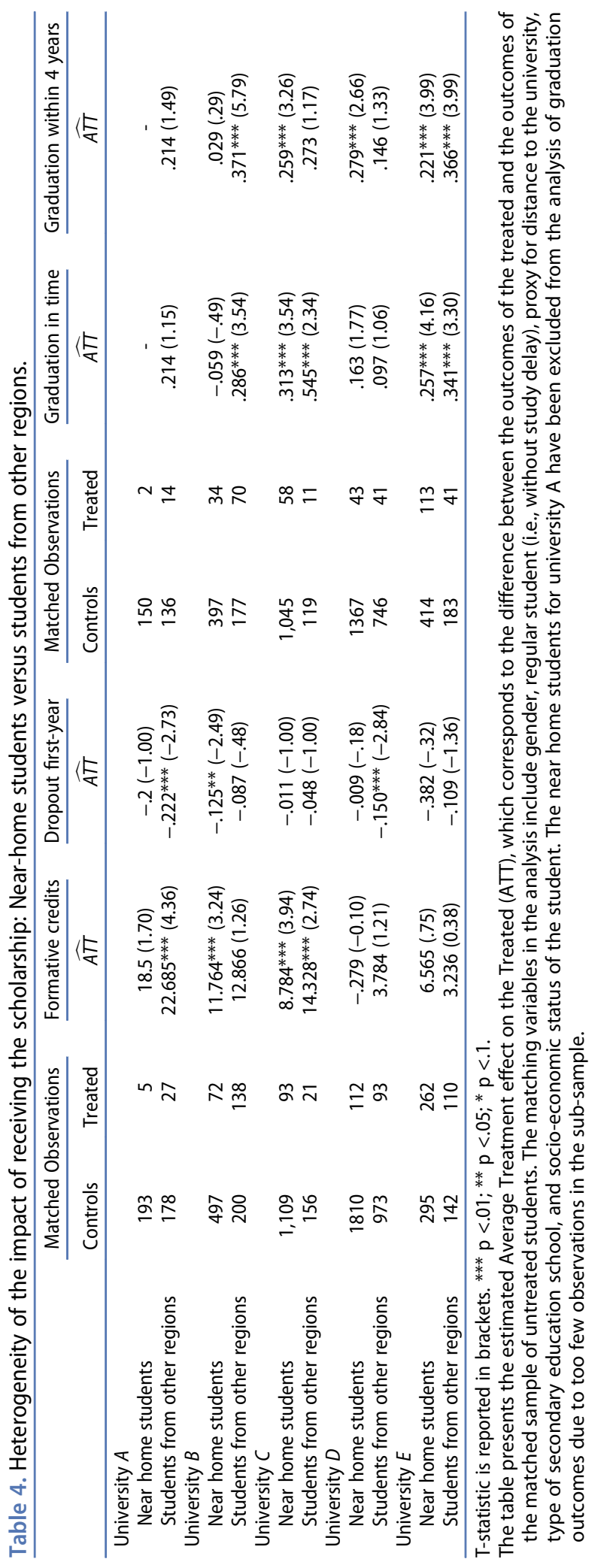




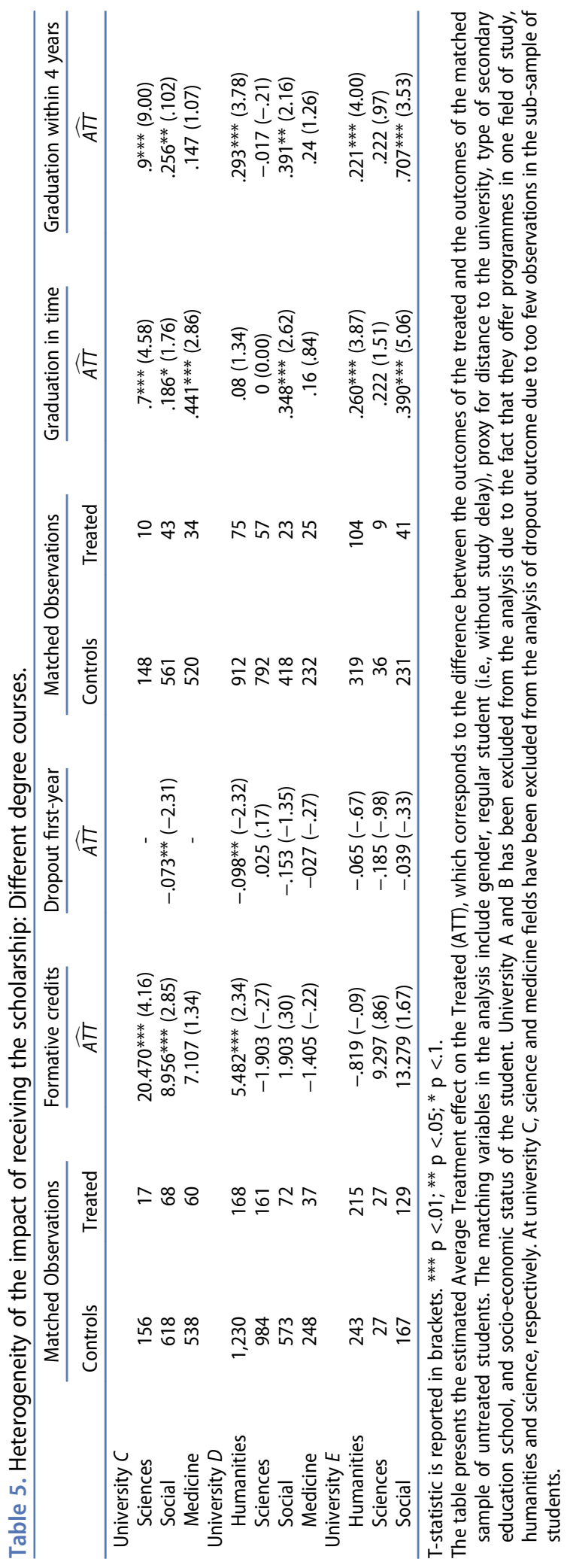




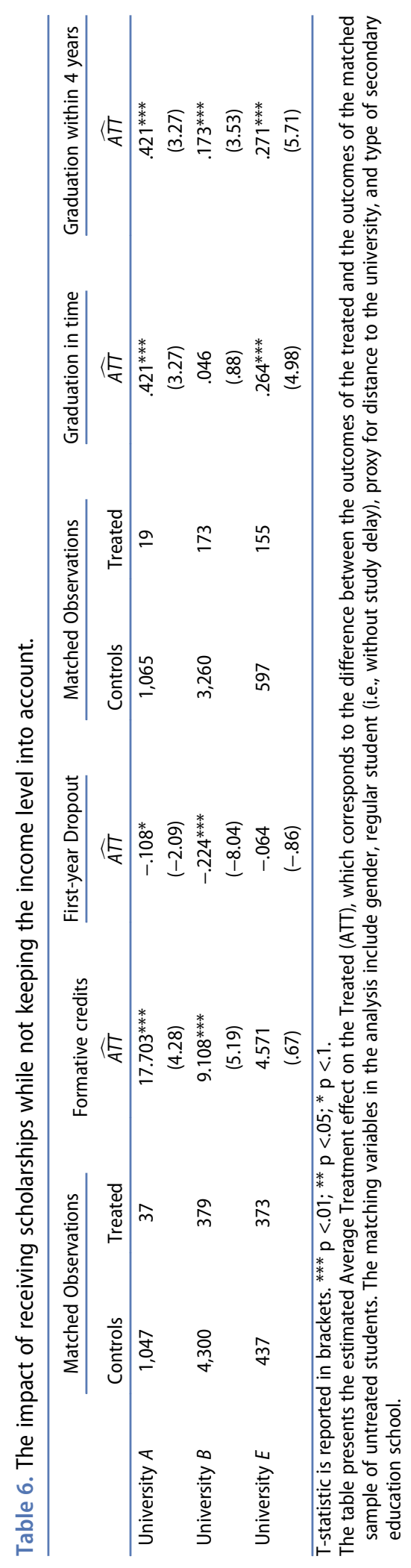


Table 7. Summary of the distribution of the Absolute Standard Bias (ASB) before and after matching.

\begin{tabular}{lcccccc}
\hline & \multicolumn{2}{c}{ Formative credits and Dropout first-year } & & \multicolumn{2}{c}{ Graduation in time and Graduation within 4 years } \\
\cline { 2 - 3 } \cline { 5 - 6 } & \% $A S B$ before matching & $\%$ ASB after matching & & \% ASB before matching & $\%$ \% ASB after matching \\
\hline University $A$ & $32.84(27.771)$ & $0(0)$ & & $40.74(26.408)$ & $0(0)$ \\
University $B$ & $27.03(25.176)$ & $3.68(3.283)$ & & $34.00(23.878)$ & $.11(.368)$ \\
University $C$ & $22.66(22.555)$ & $2.2(2.270)$ & & $23.10(19.99)$ & $3.60(2.349)$ \\
University $D$ & $36.95(41.476)$ & $.44(.519)$ & & $36.24(37.76)$ & $1.57(2.13)$ \\
University $E$ & $10.82(8.341)$ & $1.46(1.342)$ & & $18.62(13.74)$ & $3.03(2.991)$ \\
\hline
\end{tabular}

Standard deviations are reported in brackets. The table presents the ASB for both treatments: the receipt of the grant in the first academic year, if the dependent variable is the number of formative credits and dropout first year; the receipt of the scholarship in the first, second and third year, if the dependent variable is graduation. The ASB is an indicator to assess the overall distance in marginal distributions of the $X$ variables in both the control and treatment group before and after matching. As general rule, the balancing is acceptable for values of the ASB smaller of $5 \%$, after matching.

in a significant increase in the students graduating on time in most cases (three out of five universities), while, at University $\mathrm{B}$, we found that grants have a positive impact on students graduating with just a one-year delay.

To sum up, although the direction of the effect is not unequivocal and depends on what indicator is considered, the general tendency is that financial aid has a positive effect on students who decide to leave home to study - this evidence is somehow coherent with the idea of financial aid as a tool for lowering living costs.

\section{Different degree courses}

Lastly, the estimates in Table 5 show that the impact of a student receiving a grant on their performance varies according to the degree course in which they studied and the set of different outcomes we are considering.

The effect of a student's grant on the number of credits they accumulate and their dropout likelihood, when significant, is positive for humanities and social sciences. With regards to the science course, the positive impact of the grants is detected only at University C, while no significant effect is observed for either University D or University E. It is particularly interesting to note that, for medicine, this effect is never significant. Looking at the probability of students graduating, we observed that the grant had a different impact on both their degree course and the time they took to graduate. The effect of the grant also depends significantly on the type of university and the subject studied.

We can conclude that these results show a heterogeneous impact within and between universities and that both are relevant. We observed different significance levels that depend on both the investigated subpopulation within each university and the field of studies considered.

\section{Discussion and concluding remarks}

Empirical estimates reported in this paper indicate that receiving a grant results in the student achieving a higher number of credits. When compared to students with similar characteristics, students with a grant have a significantly lower probability of dropping out at or by the end of their first year. In particular, the decrease in the probability of dropping out ranged between 0.03 and 0.22 (the change is expressed in absolute terms on a scale from 0 to 1). Moreover, students who receive a grant are more likely to graduate (between 0.18 and 0.32 ) and to graduate on time (between 0.10 and 0.30 ). These results 
are rational and coherent with the objectives of financial aid policies in Italy. The size of these effects is worth noting, however. The value of these grants is quite small - as shown in previous sections - and it is actually quite surprising that they can generate such a substantial impact. Probably, the effect of obtaining a grant extends beyond the pure 'monetary' impact and brings in the students' motivation, effort and engagement. Future research should be undertaken to try and disentangle the various mechanisms behind this effectiveness.

Our findings point to several policy-related conclusions. The role of financial aid seems positive as it leads to disadvantaged students performing better, and this means that universities also perform better as a whole. In this perspective, providing financial aid does not deal with equity issues alone, but can develop higher efficiency within the HE system. Financial aid is a tool that can create the right driving force. Indeed, if universities compete with each other to attract better students (as in Agasisti, 2009), giving students the financial aid that helps them achieve better results is coherent with the strategic target of improving overall performance through market mechanisms.

The study should be interpreted with caution when debating its external validity. Two factors undermine this external validity for the whole (Italian) higher education system. Firstly, the group of universities is not representative of the complex and diversified reality of the Italian university world. All the selected universities are based in the north of Italy, where institutions of education perform relatively well compared to those in the other parts of Italy (see Agasisti \& Dal Bianco, 2006). Secondly, not all the disciplines/subjects here represented reflect their actual proportion within the overall university offer. Keeping these limitations in mind, we can conclude that our findings suggest that financial aid acts positively to improve students' results in most cases. In such perspective, a potential practical implication is to spend more money on this policy - even if this means proportionally reducing other lines of direct funding to universities.

The study of the effects of grants (and scholarships) on performance should be examined more deeply in the future, and more fine-grained administrative datasets collected.

As a final remark, these results also stimulate a reflection about the priority for future policies in the field. Should student financial aid be directed towards enlarging the number of beneficiaries maintaining the same requirements for merit (so improving the equity of interventions) or should it instead focus more on giving wider incentives to a more restricted group of excellent students, increasing the merit requirements for obtaining a grant? The analysis proposed here cannot answer this directly, and much of this discussion relies upon different political perspectives. In any case, the evidence presented in our work indicates that the equity-based system in place works, thus extending it can contribute to the equity of Italian HE system. At the same time, targeting new financial aid forms (for example, loans) to a group of particularly excellent students could also help in fostering top-level performance, pursuing a different but complementary objective of increasing the overall quality of the system.

\section{Disclosure statement}

No potential conflict of interest was reported by the authors. 


\section{ORCID}

Grazia Graziosi (D) http://orcid.org/0000-0002-8905-5985

Tommaso Agasisti (D) http://orcid.org/0000-0002-8146-3079

Kristof De Witte (D) http://orcid.org/0000-0003-0505-8642

\section{References}

Agasisti, T. (2009). Market forces and competition in university systems: Theoretical reflections and empirical evidence from Italy. International Review of Applied Economics, 23(4), 463-483. doi:10.1080/02692170902954783

Agasisti, T., \& Dal Bianco, A. (2006). Data envelopment analysis to the Italian university system: Theoretical issues and policy implications. International Journal of Business Performance Management, 8(4), 344-367. doi:10.1504/IJBPM.2006.009613

Agasisti, T., \& Murtinu, S. (2016). Grants in Italian university: A look at the heterogeneity of their impact on students' performances. Studies in Higher Education, 41(6), 1106-1132. doi:10.1080/ 03075079.2014.966670

Arendt, J.N. (2013). The effect of public financial aid on dropout from and completion of university education: Evidence from a student grant reform. Empirical Economics, 44(3), 1545-1562. doi:10.1007/s00181-012-0638-5

Avdic, D., \& Gartell, M. (2015). Working while studying? Student aid design and socioeconomic achievement disparities in higher education. Labour Economics, 33, 26-40. doi:10.1016/j. labeco.2015.01.002

Belot, M., Canton, E., \& Webbink, D. (2007). Does reducing student support affect scholastic performance? Evidence from a Dutch reform. Empirical Economics, 32(2-3), 261-275. doi:10.1007/s00181-006-0094-1

Bratti, M., Checchi, D., \& de Blasio, G. (2008). Does the expansion of higher education increase the equality of educational opportunities? Evidence from Italy. Labour, 22(Special Issue), 53-88.

Caliendo, M., \& Kopeinig, S. (2008). Some practical guidance for the implementation of propensity score matching. Journal of Economic Surveys, 22(1), 31-72. doi:10.1111/joes.2008.22.issue-1

Castleman, B.L., \& Long, B.T. (2016). Looking beyond enrollment: The causal effect of need-based grants on college access, persistence, and graduation. Journal of Labor Economics, 34(4), 1023-1073. doi:10.1086/686643

Catalano, G., \& Figà Talamanca, A. (2002). Eurostudent: le condizioni di vita e di studio degli studenti universitari italiani [Eurostudent: Living and studying conditions of Italian university students]. Bologna, Italy: Il Mulino.

Checchi, D., Fiorio, C.V., \& Leonardi, M. (2013). Intergenerational persistence of educational attainment in Italy. Economics Letters, 118(1), 229-232. doi:10.1016/j.econlet.2012.10.033

Cingano, F., \& Cipollone, A. (2007). University drop-out - The case of Italy. No. 626, Temi di discussione (Economic working papers), Bank of Italy, Economic Research and International Relations Area.

Denning, J.T. (2018). Born under a lucky star: Financial aid, college completion, labor supply, and credit constraints. The Journal of Human Resources. doi:10.3368/jhr.54.3.1116.8359R1

European Commission/EACEA/Eurydice. (2018). The European higher education area in 2018: Bologna process implementation report. Luxembourg: Publications Office of the European Union.

Garibaldi, P., Giavazzi, F., Ichino, A., \& Rettore, E. (2012). College cost and time to complete a degree: Evidence from tuition discontinuities. Review of Economics and Statistics, 94(3), 699-711. doi:10.1162/REST_a_00195

Glocker, D. (2011). The effect of student aid on the duration of study. Economics of Education Review, 30(1), 177-190. doi:10.1016/j.econedurev.2010.08.005

Graziosi, G. (2014). The role of merit-based and need-based financial aid: Evidence from Trieste University's grant programs. Italian Economic Journal, XIX(1), 103-126. 
Holland, P.W. (1986). Statistics and causal inference (with discussion). Journal of the American Statistical Association, 81(396), 945-970. doi:10.1080/01621459.1986.10478354

Mealli, F., \& Rampichini, C. (2006). I metodi e i modelli per la valutazione degli effetti delle borse di studio, in L'efficacia delle politiche di sostegno agli studenti universitari. In L. Biggeri \& G. Catalano (Eds.), L'esperienza italiana nel panorama internazionale (pp. 139-155). Il Mulino, Bologna.

Mealli, F., \& Rampichini, C. (2012). Evaluating the effects of university grants by using regression discontinuity designs. Journal of the Royal Statistical Society A, 175, 775-798. doi:10.1111/ j.1467-985X.2011.01022.x

OECD. (2017a). Educational attainment: A snapshot of 50 years of trends in expanding education, education indicators in focus, no. 48. Paris: Author. doi:10.1787/409ceb2b-en

OECD. (2017b). Education at a glance 2017: OECD indicators. Paris: Author. doi:10.1787/eag2017-en

Page, L.C., Kehoe, S.S., Castleman, B.L., \& Sahadewo, G.A. (2017). More than dollars for scholars: The impact of the Dell Scholars Program on college access, persistence and degree attainment. Journal of Human Resources, University of Wisconsin Press, 54(3), 683-725.

Page, L.C., \& Scott-Clayton, J. (2016). Improving college access in the United States: Barriers and policy responses. Economics of Education Review, 51, 4-22. doi:10.1016/j.econedurev.2016.02.009

Rosenbaum, P.R., \& Rubin, D.B. (1983). The central role of the propensity score in observational studies for causal effects. Biometrika, 70(1), 41-55. doi:10.1093/biomet/70.1.41

Rubin, D.B. (1974, Oct). Estimating causal effects of treatments in randomized and nonrandomized studies. Journal of Educational Psychology, 66(5), 688-701. doi:10.1037/h0037350

Sianesi, B. (2004). An evaluation of the active labour market programmes in Sweden. The Review of Economics and Statistics, 86(1), 133-155. doi:10.1162/003465304323023723 